\title{
Combatting the silent shisha epidemic in Nigeria: The need for public health education
}

\author{
Kehinde K. Kanmodi ${ }^{1}$, Precious A. Kanmodi ${ }^{1}$
}

AFFILIATION

1 Tobacco Research and Advocacy Group, Cephas Health Research Initiative Inc, Ibadan, Nigeria

\section{CORRESPONDENCE TO}

Kehinde K. Kanmodi. Tobacco Research and Advocacy Group, Cephas Health Research Initiative Inc, Ibadan, Nigeria. E-mail: kanmodikehinde@ yahoo.com

Popul. Med. 2020;2(June):18
KEYWORDS

education, public health, epidemic, Nigeria, shisha

Received: 14 April 2020, Revised: 22 April 2020, Accepted: 2 May 2020

https://doi.org/10.18332/popmed/120967

\section{Dear Editor,}

Shisha smoking is a way of smoking tobacco, sometimes mixed with fruit or molasses sugar, through the mouthpiece of a bowl hose or tube ${ }^{1}$. Although the practice of shisha smoking started in the Middle East, it has spread to several other parts of the world, including Nigeria ${ }^{2}$. In Nigeria, the prevalence rate of shisha smoking, especially among the youth, is rising, making it an issue of public health concern ${ }^{3}$. The rising prevalence of shisha smoking in Nigeria can be attributed to the increase in the openings of new shisha lounges/bars, subtle advertisement of shisha in public places, social acceptance of shisha smoking, peer influence, and public misconceptions about the safety profile of shisha use $^{3,4}$.

In May 2015, the bill prohibiting tobacco smoking in public places in Nigeria - Tobacco Control Bill - was passed into law by the Federal Government of Nigeria ${ }^{3,5}$. Unfortunately, many public shisha smoking places have opened in major cities across Nigeria, even after the enactment of the Tobacco Control Law ${ }^{3}$. In a 2015 technical report by the World Health Organization (WHO) Study Group on Tobacco Product Regulation (TobReg), it was reported that many countries, including Nigeria, lack specific policy regulating shisha smoking among their populace $\mathrm{e}^{4,6}$.

It is also noteworthy that most of the existing public health education programmes on tobacco in Nigeria have focused only on cigarettes, with little to no attention on shisha. It is of concern that many shisha smokers in Nigeria lack adequate knowledge of the health risks associated with shisha smoking? .

In order to combat the shisha epidemic in Nigeria, shisha tobacco control law should be enacted. Enacting this law by the Federal Government of Nigeria is not enough to combat the epidemic of shisha use in Nigeria. To effectively reduce the rate of shisha tobacco smoking in Nigeria we recommend the use of public health education interventions, which should be focused on positively changing people's attitude towards shisha, on how to resist peer pressure to smoke, and to cover the health and socioeconomic hazards associated with shisha use and aspects of making shisha smoking a socially unacceptable habit ${ }^{8}$.

\section{REFERENCES}

1. British Heart Foundation. Shisha. https://www.bhf.org. uk/heart-health/risk-factors/smoking/shisha. Accessed December 1, 2019.

2. Akl EA, Gaddam S, Gunukula SK, Honeine R, Jaoude PA, Irani J. The effects of waterpipe tobacco smoking on health outcomes: a systematic review. Int J Epidemiol. 2010;39(3):834-857. doi:10.1093/ije/dyq002

3. Lasebikan VO, Ola BA, Lasebikan TO. Shisha smoking in selected nightclubs in Nigeria. Pan Afr J Med. 2019;33:136. doi:10.11604/pamj.2019.33.136.17149

4. Abraham EA, Egbe CO, Ayo-Yusuf OA. News media coverage of shisha in Nigeria from 2014 to 2018. Tob Induc Dis. 2019;17(April). doi:10.18332/tid/106139

5. Omaduvie U, Adisa A. Exposure to secondhand smoke in home and public areas among adolescents in Abuja, Nigeria: Tobacco control implications. Tobacco Prev Cessation. 2015;1(December). doi:10.18332/tpc/61178

6. World Health Organization. Advisory note: waterpipe tobacco smoking: health effects, research needs and recommended actions by regulators. Geneva, Switzerland: World Health Organization; 2015. https://apps.who.int/iris/ bitstream/handle/10665/161991/9789241508469_eng. pdf;jsessionid= DDBA6A244E30221F5077F469F9EF2BBC? sequence=1. Accessed April 22, 2020.

7. Kanmodi KK, Mohammed FA, Nwafor NJ, et al. Poor knowledge of the harmful effects of shisha among shisha smokers: Findings from a preliminary survey in Northwest Nigeria. Med 
Univ. 2019;2(2):49-56. doi:10.2478/medu-2019-0009

8. Dadipoor S, Kok G, Aghamolaei T, Heyrani A, Ghaffari M, Ghanbarnezhad A. Factors associated with hookah smoking among women: A systematic review. Tob Prev Cessation. 2019;5(August). doi:10.18332/tpc/110586 